\title{
Information and Communications Technologies (ICTs) in Education for Sustainable Development: A Bibliographic Review
}

\author{
José Juan Carrión-Martínez ${ }^{1}$, Antonio Luque-de la Rosa ${ }^{1} \mathbb{D}$, José Fernández-Cerero ${ }^{2}$ and \\ Marta Montenegro-Rueda ${ }^{2, *(D)}$ \\ 1 Department of Education, University of Almeria, 04120 Almeria, Spain; jcarrion@ual.es (J.J.C.-M.); \\ aluque@ual.es (A.L.-d.l.R.) \\ 2 Department of Teaching and Educational Organization, University of Seville, 41013 Seville, Spain; \\ jfercerero@gmail.com \\ * Correspondence: mmontenegro1@us.es; Tel.: +34-955-42-07-75
}

Received: 29 March 2020; Accepted: 15 April 2020; Published: 17 April 2020

\begin{abstract}
In recent years, technological advances have played a very important role in our society, as well as in different educational contexts, including Education for Sustainable Development. Information and Communication Technologies (ICTs), which have made it possible to improve the quality of life of many people. The aim of this study is to review the scientific evidence on the use of ICTs for Sustainable Development. Following the Preferred Reporting Items for Systematic Reviews and Meta-Analyzes (PRISMA) guidelines, a bibliographic search was carried out using the Web of Science and Scopus bibliographic repositories, with a total of 19 articles comprising the final sample for review. The results show that the most preeminent strategies used are mobile learning and distance education, which are related to the achievement of the sustainable development goals. Included among the conclusions of this study is the need to investigate the different strategies that are being carried out, with ICTs in school aimed at developing a more sustainable environment standing out.
\end{abstract}

Keywords: ICT; sustainable development; education; indexations; reviews

\section{Introduction}

Information and Communication Technologies (ICT) have contributed to the development of our society, drastically transforming the way we live, especially in developed countries. These types of tools affect the way we communicate, connect with each other or work, and are key to the development of areas such as health, economy or education [1]. Thus, at an individual level, ICTs affect people's daily lives, but at the macro level, these types of tools aim to contribute to the development of a more sustainable future, reducing poverty, improving health, education and the quality of life of many people [2].

Quality education is a human right and is the main tool for eradicating poverty, guaranteeing inclusive education and creating learning opportunities, as established in the objectives for sustainable development [3]. Accordingly, ICTs have become indispensable tools in the fulfillment of this objective, and to deal with different societal needs through a transformation of educational practices [4]. Digital tools help reduce social and economic inequalities that may exist in society, as well as favor the inclusion of people, provided that there is equality of opportunity [5], this being due to different variables such as its low cost or flexibility, among others [2].

While it is unclear if this relationship is due to an increase in people's awareness, economic savings or legislative changes, around the world there is growing concern for the environment, as well as for 
sustainable technologies. Likewise, it is necessary to recognize how ICTs have become an element of promotion and development in society, in the economic, political and educational spheres [6].

The evolution and expansion of technological tools have become one of the more promising aspects of the changes and advances experienced by today's society, influencing very rapid changes in people's daily lives, particularly in those of younger generations [7]. This aspect makes it necessary to assess how ICTs have been incorporated into teaching practices as a way of transforming the teaching-learning processes of students.

This research aims to assess the possibilities offered by ICT in Education for Sustainable Development, and is based on a review of the research published in the last decade in two of the principal scientific databases at the international level.

\section{ICTs in Education for Sustainable Development}

Technology is becoming increasingly present in different areas of society, impacting on people's daily lives. The transformations in the field of educational are a reflection of this. These advances have facilitated the development of new educational practices that improve the teaching-learning processes of students [8].

The new educational practices seek equality and respect for differences between people. This would be impossible without the inclusion of technologies in education that promote the development of new methods and forms of learning that reduce inequalities and makes it more inclusive [9]. Thus, it is not only a question of using ICT in the classroom, but rather one of proposing methodological changes that transform the quality of life of people for a more sustainable approach.

Since the United Nations Organization set goals that sought to solve some of society's most pressing problems, such as ending poverty, guaranteeing a quality education, inclusion or the reduction of inequalities, the concept of sustainable development has generated a greater interest in education in recent years [10]. These goals offer the educational community a new opportunity to develop good practices in education aimed at improving teaching, as well as educating in a sustainable world [11]. All this implies changes in study programs, including measures such as the integration of technologies within their programs [12].

Education is essential for solving the problems that exist in society and for promoting sustainable development [13]. This development can evolve through technological education, which can contribute to the creation of numerous learning opportunities. Given the growing interest and research carried out in recent years in the field of ICT in Education for Sustainable Development, this study has been carried out in order to understand how the use of ICT is being implemented in classrooms focused on a more sustainable education.

\section{Objectives and Research Questions}

In this context, the objectives of this study are to:

1. Evaluate the general state of research on the use of ICT for Sustainable Development.

2. Analyze the main themes and lines of research in this field.

In turn, the following research questions are explored:

Q1. What is the general state of research in the field of ICT in Education for Sustainable Development?

Q2. Which countries generate the greatest volume of scientific production in this field?

Q3. What has been the citation impact of the various articles analyzed?

Q4. What research designs predominate in the studies analyzed?

Q5. What are the main lines of research within the domain of ICT in Education for Sustainable Development?

Q6. What areas could be addressed in future research studies? 


\section{Methodology}

\subsection{Search Design}

From a methodological point of view, establishing the relevance of the sources and the representativeness of the sample are two fundamental aspects. Thus, taking into account the characteristics of this study, a systematic review of the literature on studies that address the use of ICT in education for sustainable development has been carried out using the most prestigious scientific databases, Web of Science (WoS) and Scopus. The selection of these databases is due to two main reasons, firstly, the prestige and international recognition of these tools, since they are currently considered to be the principal sources for locating scientific publications with the greatest impact. However, the suitability of exploring other international databases and repositories has also been assessed for future investigations, which could complement this study. Secondly, the representativeness of the sample is supported by the international prestige of the databases and their required indexing protocols, and also by the specific delimitation of a series of search criteria and a definitive procedure. In this sense, the sample is made up of a total of 19 articles.

For the selection of documents for this study, all the research written in English or Spanish in the last decade (January 2009-December 2019) has been taken into account. Although there were numerous search terms, the search sequence has been carried out using keywords. Initially, these keywords were: education for sustainable development; learning for sustainable development; ICT; technology; and digital technology.

This review has taken into account the quality standards of the Preferred Reporting Items for Systematic Reviews and Meta-Analyzes (PRISMA) statement for systematic reviews [14], as well as the application of descriptive and qualitative methodologies, and the application of semantic techniques to the analysis of social networks for subsequent visual representation with VOSviewer software [15].

\subsection{Selection Process and Data Extraction}

The inclusion criteria were publications that were: (1) published in Spanish or English; (2) addressed the use of ICTs in Education for Sustainable Development; (3) included the search descriptors in the title, abstract and/or keywords; (4) open publications; (5) journal articles. Regarding the exclusion criteria, the following were eliminated: (1) conference proceedings, book chapters, books, theses or reviews; (2) studies outside the educational context; (3) duplicated articles; (4) publications with restricted access. The exclusive selection of scientific articles, disregarding other formats, is mainly due to the search for texts that can be considered impactful.

For their selection, the factor of eligibility was first used, using the search descriptors in the title, abstracts and/or keywords, to subsequently carry out an exhaustive review analyzing the full texts. References or citations to the selected articles were searched. Thus, the data collection was divided into four phases: identification, screening, eligibility and inclusion.

In the first phase, that of identification, an initial search retrieved a total of 305 records from the selected databases (118 from Web of Science and 187 from Scopus). An additional search for citations to the selected articles was also carried out. Figure 1 shows the evolution of scientific production in the last decade in this field:

In the next phase, that of screening, the number of duplicate articles were excluded, a total of 102 records. Subsequently, in the eligibility phase, the articles were reviewed according to the aforementioned inclusion and exclusion criteria. This eligibility review found 184 documents that did not meet all the aforementioned criteria, since 36 were published in languages other than English or Spanish, 45 were eliminated due to the type of document (doctoral theses, books, communications, conference proceedings or technical reports), 87 clearly belonged to other knowledge areas and 35 did not permit access to the full text. Consequently, in the final inclusion phase, a total of 19 articles were established as the final sample considered in this review. Figure 2 presents a flow chart of the selection process for scientific articles. 


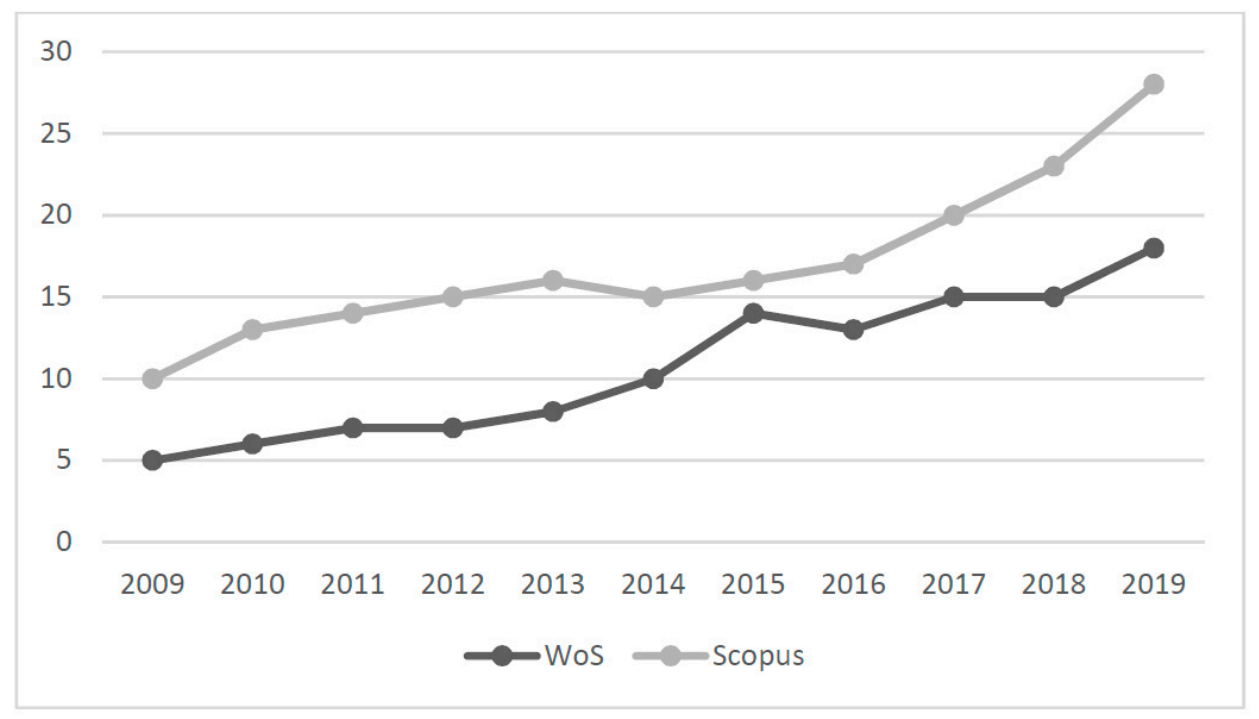

Figure 1. Evolution in the articles published per year in source databases.

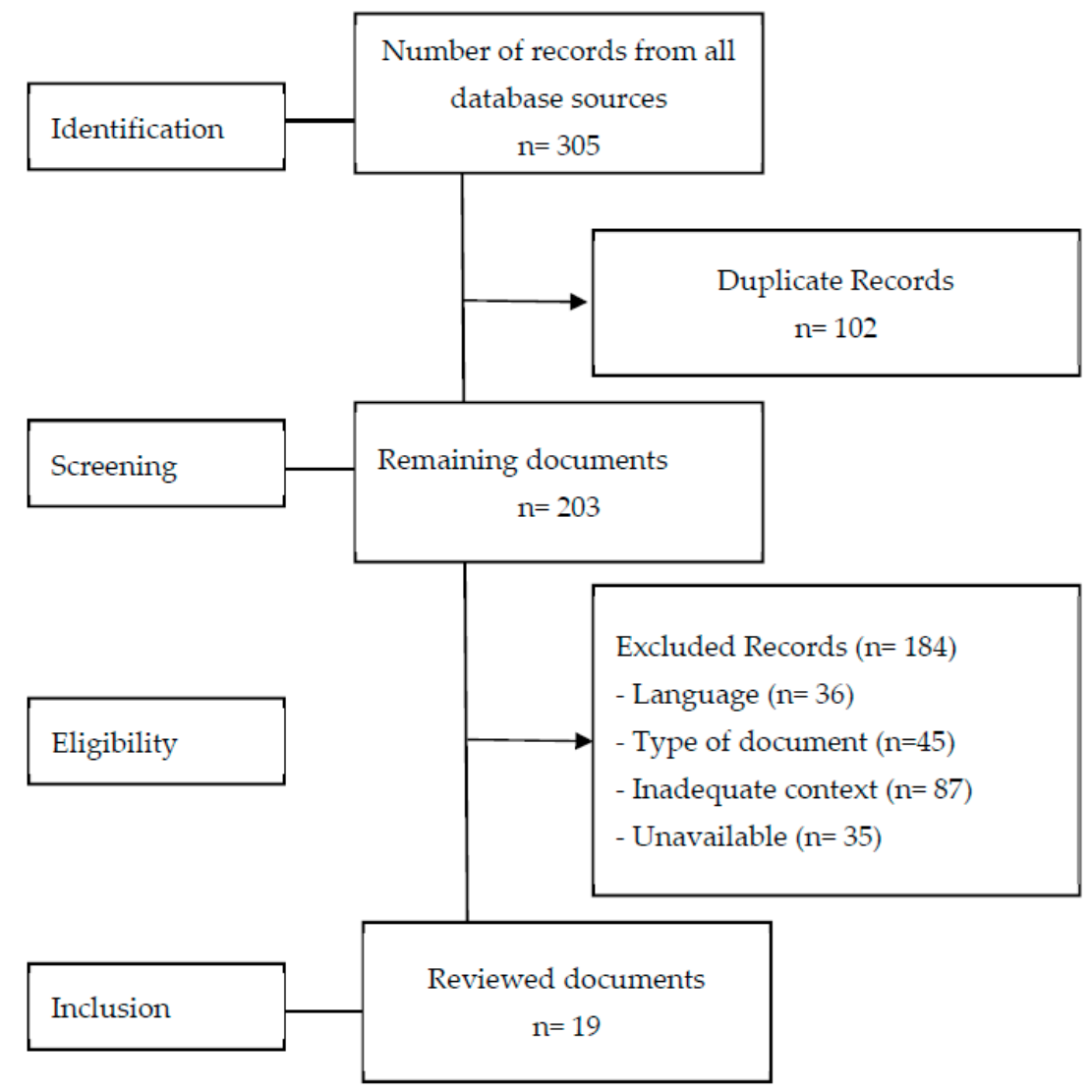

Figure 2. Sample flow chart.

Subsequently, for the analysis and discussion procedure, the selected articles have been coded in a database and the information used to create graphs and tables. Table 1 shows a summary of the detailed analysis of the 19 articles that have been selected for the review, indicating all the relevant information for the review. 
Table 1. Analysis of Selected Articles.

\begin{tabular}{|c|c|c|c|c|c|c|}
\hline \multirow{2}{*}{ Article } & \multirow{2}{*}{ Year } & \multirow{2}{*}{ Methodology } & \multirow{2}{*}{ Main Contributions } & \multirow{2}{*}{ Country } & \multicolumn{2}{|c|}{ Cites } \\
\hline & & & & & 1 & 2 \\
\hline $\begin{array}{c}\text { [12] McGarr, } \\
\text { O. }\end{array}$ & 2009 & Qualitative & $\begin{array}{l}\text { The inclusion of ICTs in the } \\
\text { classroom promotes } \\
\text { sustainable development }\end{array}$ & $\begin{array}{l}\text { United } \\
\text { Kingdom }\end{array}$ & 3 & 3 \\
\hline $\begin{array}{l}\text { [16] Purg, P. \& } \\
\text { Zakrajsek, S. }\end{array}$ & 2009 & Qualitative & $\begin{array}{c}\text { These tools improve time } \\
\text { management as well as } \\
\text { motivating students }\end{array}$ & Slovenia & 0 & 4 \\
\hline $\begin{array}{l}\text { [17] Grönlund, } \\
\text { A. \& Islam, } \\
\text { Y.M. }\end{array}$ & 2010 & Qualitative & $\begin{array}{l}\text { The use of interactive } \\
\text { technologies (mobile phones) is } \\
\text { considered feasible for } \\
\text { sustainable development }\end{array}$ & India & 27 & 37 \\
\hline $\begin{array}{l}\text { [18] Zhou, C. } \\
\text { Purushothaman, } \\
\text { A. \& } \\
\text { Rongbutsri, N. }\end{array}$ & 2013 & Mixed & $\begin{array}{l}\text { The use of Web } 2.0 \text { promotes } \\
\text { the construction of knowledge, } \\
\text { reflection and the exchange of } \\
\text { information among } \\
\text { communities }\end{array}$ & Denmark & 5 & 4 \\
\hline $\begin{array}{l}\text { [19] Kadir, H., } \\
\text { Kadir, M., } \\
\text { Yusuf, T.M. \& } \\
\text { Rashed, D. }\end{array}$ & 2014 & Quantitative & $\begin{array}{l}\text { ICTs influence the development } \\
\text { of a positive attitude towards } \\
\text { the acquisition of new skills. }\end{array}$ & Nigeria & 0 & 0 \\
\hline $\begin{array}{l}\text { [20] } \\
\text { Altomonte, S. } \\
\text { et al. }\end{array}$ & 2016 & Qualitative & $\begin{array}{l}\text { E-Learning and M-Learning the } \\
\text { time and pace of student's } \\
\text { learning processes }\end{array}$ & $\begin{array}{l}\text { United } \\
\text { Kingdom }\end{array}$ & 8 & 5 \\
\hline $\begin{array}{l}\text { [21] } \\
\text { Cukurbasi, B, } \\
\text { Isbulan, O. \& } \\
\text { Chopper, M. }\end{array}$ & 2016 & Quantitative & $\begin{array}{l}\text { The use of tablets is beneficial } \\
\text { and increases the interest } \\
\text { students have in learning }\end{array}$ & Turkey & 3 & 3 \\
\hline $\begin{array}{l}\text { [22] } \\
\text { Kalogiannakis, } \\
\text { M. \& } \\
\text { Papadakis, S. }\end{array}$ & 2017 & Qualitative & $\begin{array}{c}\text { Mobile devices and QR codes } \\
\text { facilitate access to information } \\
\text { without the restrictions } \\
\text { imposed by time and space }\end{array}$ & Greece & 0 & 6 \\
\hline [23] Chou, P.N. & 2018 & Mixed & $\begin{array}{l}\text { The use of drones improves } \\
\text { students to acquisition new } \\
\text { skills }\end{array}$ & Taiwan & 2 & 2 \\
\hline $\begin{array}{l}\text { [4] Del Cerro } \\
\text { Velázquez, F. \& } \\
\text { Morales } \\
\text { Méndez, G. }\end{array}$ & 2018 & Quantitative & $\begin{array}{l}\text { Augmented reality and the use } \\
\text { of mobile devices facilitates the } \\
\text { teaching-learning process and } \\
\text { eliminates barriers for those } \\
\text { students with particular special } \\
\text { education needs }\end{array}$ & Spain & 7 & 10 \\
\hline [24] Kim, S. & 2018 & Quantitative & $\begin{array}{l}\text { ICTs improve the performance } \\
\text { of immigrant students and } \\
\text { helps them to integrate into } \\
\text { society }\end{array}$ & USA & 0 & 3 \\
\hline $\begin{array}{l}\text { [25] Plaza-De } \\
\text { la Hoz, J. }\end{array}$ & 2018 & Qualitative & $\begin{array}{l}\text { ICTs promote the development } \\
\text { of a sustainable society as long } \\
\text { as their use and structure are } \\
\text { deemed to be appropriate }\end{array}$ & Spain & 0 & 0 \\
\hline $\begin{array}{l}\text { [26] Tu, S., Yan, } \\
\text { X, Jie, K, Yin, } \\
\text { M. \& Huang, } \\
\quad \text { C. }\end{array}$ & 2018 & Mixed & $\begin{array}{l}\text { Mobile technology and the } \\
\text { Internet are two resources } \\
\text { which promote student } \\
\text { learning as they are free, } \\
\text { portable, sustainable and } \\
\text { interactive }\end{array}$ & Spain & 0 & 1 \\
\hline
\end{tabular}


Table 1. Cont.

\begin{tabular}{|c|c|c|c|c|c|c|}
\hline \multirow{2}{*}{ Article } & \multirow{2}{*}{ Year } & \multirow{2}{*}{ Methodology } & \multirow{2}{*}{ Main Contributions } & \multirow{2}{*}{ Country } & \multicolumn{2}{|c|}{ Cites } \\
\hline & & & & & 1 & 2 \\
\hline $\begin{array}{l}\text { [27] } \\
\text { Zhalgasbekova, } \\
\text { Z.K. et al. }\end{array}$ & 2018 & Qualitative & $\begin{array}{l}\text { The use of a mobile app } \\
\text { improves the knowledge } \\
\text { acquisition process of students }\end{array}$ & Kazakhstan & 0 & 2 \\
\hline $\begin{array}{l}\text { [28] Bennis, L. } \\
\text { \& Amali, S. }\end{array}$ & 2019 & Quantitative & $\begin{array}{l}\text { M-Learning and education } \\
\text { based on games is fundamental } \\
\text { for improving learning at any } \\
\text { time in any place }\end{array}$ & Morocco & 0 & 0 \\
\hline $\begin{array}{l}\text { [29] } \\
\text { Díaz-Lauzurica, } \\
\text { B. \& } \\
\text { Moreno-Salinas, } \\
\text { D. }\end{array}$ & 2019 & Mixed & $\begin{array}{l}\text { Computational thinking and } \\
\text { robotics equip students with } \\
\text { useful life skills and increase } \\
\text { their motivation and levels of } \\
\text { interest }\end{array}$ & Spain & 0 & 0 \\
\hline $\begin{array}{l}\text { [30] Hegarty, B. } \\
\text { \& Thompson, } \\
\text { M. }\end{array}$ & 2019 & Mixed & $\begin{array}{l}\text { The use of mobile devices } \\
\text { promotes learning and a more } \\
\text { sustainable system of education }\end{array}$ & $\begin{array}{c}\text { New } \\
\text { Zealand }\end{array}$ & 0 & 0 \\
\hline $\begin{array}{l}\text { [31] Lim, K., } \\
\text { Kim, Y., Kim, } \\
\text { M., Jang, Y. \& } \\
\text { Joo, M.H. }\end{array}$ & 2019 & Mixed & $\begin{array}{l}\text { The use of digital environments } \\
\text { (tablets) can reduce the } \\
\text { differences between urban and } \\
\text { rural areas }\end{array}$ & South Korea & 0 & 0 \\
\hline $\begin{array}{l}\text { [32] Verma, P. } \\
\text { \& Trivedi, A. }\end{array}$ & 2019 & Qualitative & $\begin{array}{l}\text { On-line education promotes } \\
\text { students' learning, despite its } \\
\text { scarce popularity }\end{array}$ & India & 0 & 0 \\
\hline
\end{tabular}

Note: $1=$ WoS; $2=$ Scopus.

\section{Results}

After analyzing the results of the search, a total of 19 documents were selected as the final sample of the systematic review that met the inclusion and exclusion criteria. The studies, as can be seen in Table 1, have been ordered by year of publication, although the first one is from 2009, since that year, production has been increasingly relevant. It should be noted that most of them have been published in 2018 and 2019.

A large number of studies have been carried out by various authors, as well as in various countries around the world. Figure 3 displays how the majority of the scientific production is concentrated in countries in Europe, followed by Asia.

The highest index of article publications, in both databases, was found in 2019 (28 in Scopus and 18 in WoS). These publications are registered in the different quartiles corresponding to the databases. Likewise, the low impact that this topic has is striking, since in most of the publications the impact of citations received in both databases is very low (Table 2).

Regarding the type of methodology used, as seen in Table 1, most of the articles utilize a qualitative approach $(42.11 \%)$, followed by those that utilize mixed (31.58\%) or quantitative methodology $(26.32 \%)$.

Regarding the type of Information and Communication Technology (ICT) in Education for Sustainable Development, we find that M-Learning (36.84\%) and E-Learning (15.79\%), are mainly applied in education centers, as can be seen in Figure 4.

These types of technological tools facilitate sustainable development, while developing the acquisition of knowledge and learning of students (36.84\%), improving time management and the pace of learning $(26.32 \%)$, increasing motivation and student interest $(21.05 \%)$ or reducing differences between people $(15.79 \%)$. 


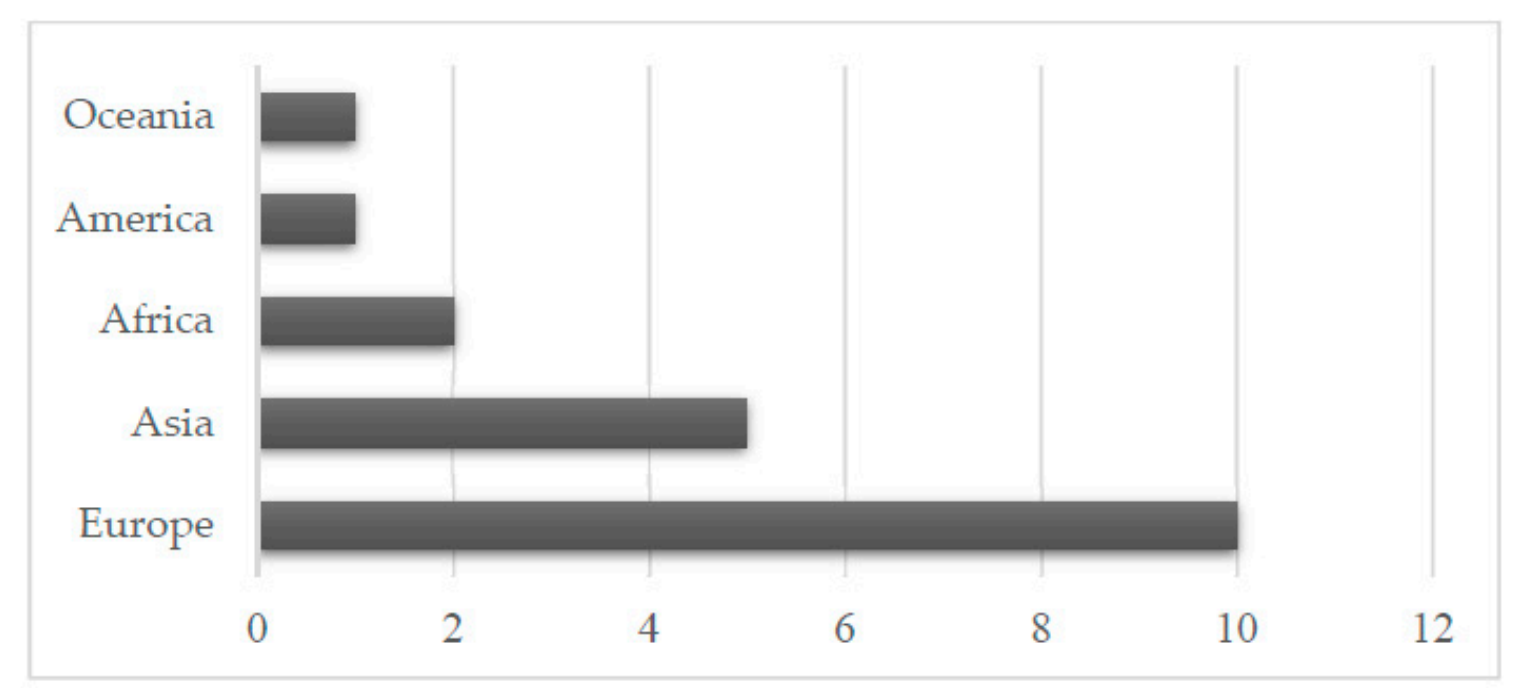

Figure 3. Distribution of Publications by Continent.

Table 2. Number of articles cited per year.

\begin{tabular}{ccc}
\hline \multirow{2}{*}{ Cites } & \multicolumn{2}{c}{ Database 2009-2019 } \\
\cline { 2 - 3 } & WoS & Scopus \\
\hline $\mathbf{0}$ & 12 & 7 \\
$\mathbf{1}$ & 0 & 1 \\
$\mathbf{2}$ & 1 & 2 \\
$\mathbf{3}$ & 2 & 3 \\
$\mathbf{4}$ & 0 & 2 \\
$\mathbf{5}$ & 1 & 1 \\
$\mathbf{6}$ & 0 & 1 \\
$\mathbf{7}$ & 1 & 0 \\
$\mathbf{8}$ & 1 & 0 \\
$\mathbf{9}$ & 0 & 0 \\
$\mathbf{1 0}$ & 0 & 1 \\
$>\mathbf{1 0}$ & 1 & 1 \\
\hline
\end{tabular}

Once the sample set of documents have been descriptively and quantitatively analyzed, the analysis of the relationships established between the automatically extracted keywords or Key Words Plus (KW+) from the different databases are represented using the VOSviewer program.

Among the 19 studies selected in the last decade, a total of $77 \mathrm{KW}+$ have been extracted. In the following figure (Figure 5), it can be seen how, in accordance with the degree of similarity of the KW+, three groups or clusters have been formed that define the main research themes in this field. The size of each circle or node is indicative of the relevance of each descriptor in this review, while the links or distance between the nodes reflects the relationships between them. The weight of a descriptor indicates its importance. A descriptor with a higher weight is considered more important than one with a lower weight. 


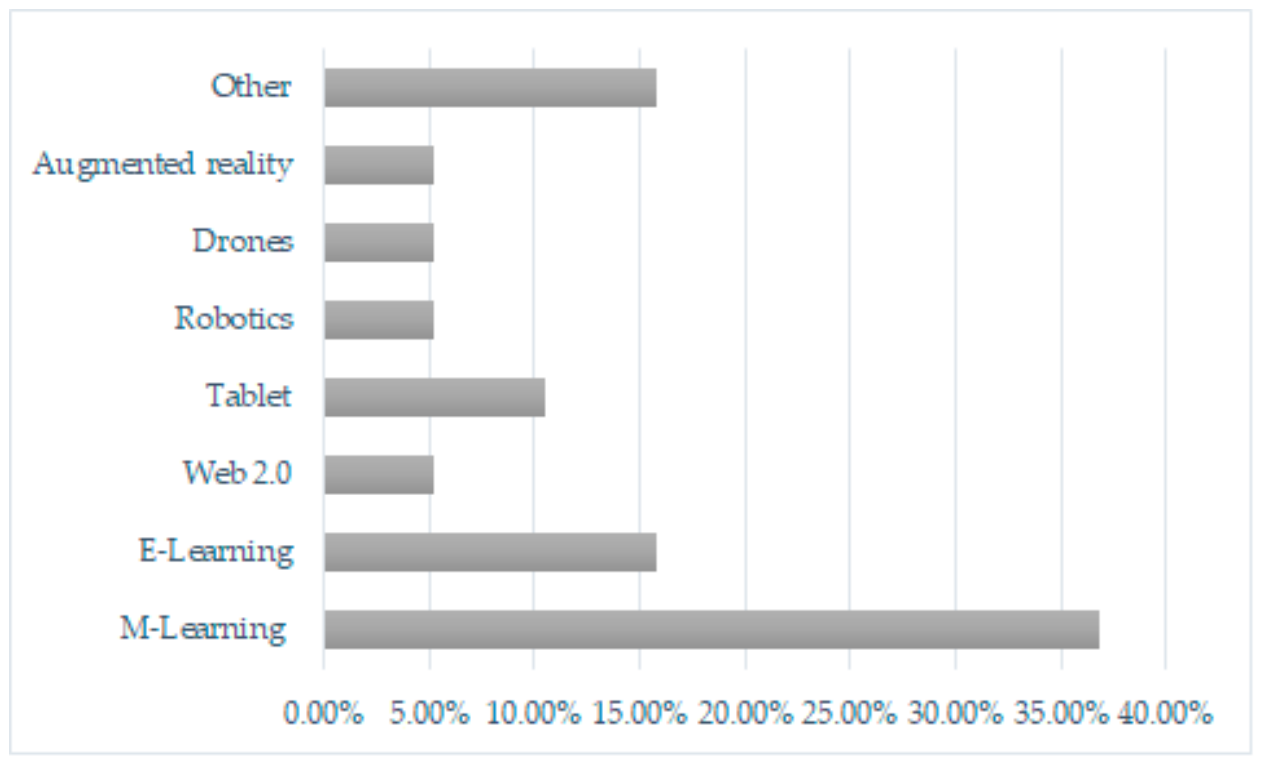

Figure 4. Information and Communication Technologies (ICTs) applied to Education for Sustainability.

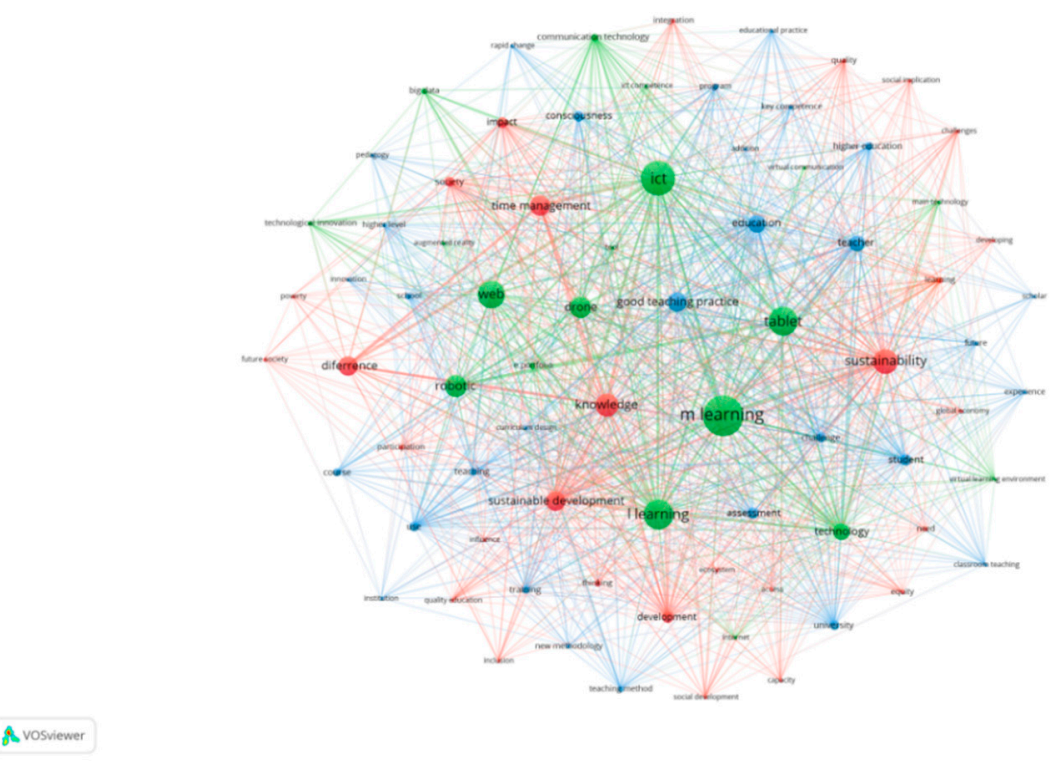

Figure 5. Bibliometric Cluster Map.

With regards to the three thematic clusters displayed in Figure 5, the following can be highlighted:

Cluster 1: identified in red, is related to the principal theme of this study, the use of ICT in Education for Sustainable Development, as well as its benefits. Some of the descriptors are: sustainability (weight $=68)$, knowledge (weight $=60)$, time management $($ weight $=47)$.

Cluster 2: represented in blue, is related to good educational practices with ICT for Sustainable Development. Among the descriptors we can find: good teaching practices (weight $=45$ ), consciousness (weight $=24)$, teacher $($ weight $=18)$.

Cluster 3: appears green, is related to the main Information and Communication Technologies that are being used in Education for Sustainable Development. The following descriptors stand out: m-learning (weight $=154)$, ICT $($ weight $=132)$, l-learning $($ weight $=124)$.

Likewise, we can observe the level of relevance of the descriptors in the second bibliometric density map, graded according to their color (Figure 6). 


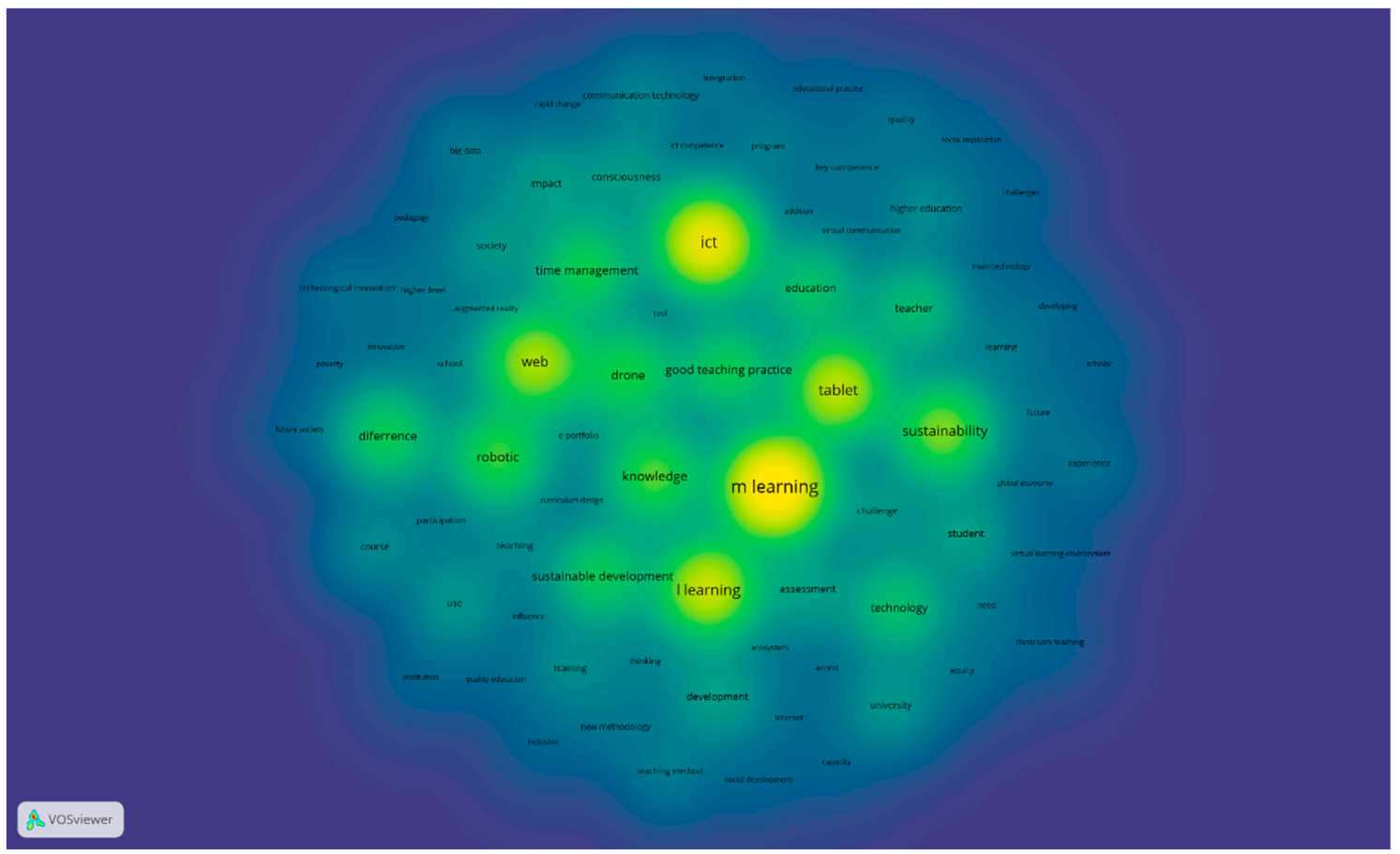

Figure 6. Bibliometric Density Map.

The central area of the map (in yellow): this central area and the graded colors close to it in yellow show a high density of $\mathrm{KW}+$ co-occurrences, that is, greater relevance in research in this field. Among them we can find ICT (weight $=132$ ), good teaching practices (weight $=45)$, m-learning (weight $=154$ ).

Peripheral area of the map (green color): the peripheral areas and those closest to green indicate less density, so they are even less relevant. Among them we can find augmented reality (weight=7), quality education (weight $=8$ ), social implication (weight $=9$ ).

\section{Conclusions and Discussion}

Regarding the first research question (Q1), in relation to the general state of research in the field of ICT in Education for Sustainable Development, the main conclusion is that scientific production in the last decade is still in an initial and expansion phase. The generalized use of ICT in the classroom is a main topic of current interest. However, particular references to its use in Education for Sustainable Development are considerably fewer. In this review, we have been able to verify that, although studies have been carried out throughout the decade, this topic has recently become especially relevant, since most of the production has taken place in the last two years in the WoS and Scopus databases, an aspect that is consistent with other studies [33,34]. This leads us to the reflection that, in an educational environment which has become increasingly digital, ICT should not be used merely as a support resource or as something exceptional, but rather, should be carried out during pedagogical practices aimed at creating a more sustainable model. To this end, teachers need to have receive relevant training in the use of appropriate ICTs $[25,35]$.

This last aspect is related to the second research question $(\mathrm{Q} 2)$, which mentions the scientific production that has been carried out in this field in the different countries in the last decade. As mentioned above, at a global level, the scientific literature in this field published in the last decade is both of interest and has relevance. However, its global distribution has been uneven. The results show that European countries, followed by Asian nations, have been the most prolific, a result which is consistent with other studies, such as that of Maestre Góngora [36].

With reference to the third question (Q3), research in this field is becoming increasingly relevant, although it is still very insignificant, since the citations these impact articles receive are still very low. 
Most of them don't receive any citations. This is evidence that it is an area still in expansion and development [36].

In relation to research designs $(\mathrm{Q} 4)$, articles with qualitative methodology predominate $(42.11 \%)$, followed by those with mixed methods ( $31.58 \%)$ and, to a lesser extent, quantitative studies $(26.32 \%)$.

Regarding question five (Q5), which pertains to the main lines of research in this field, we can highlight that ICTs are becoming increasingly important in the development of innovative educational practices, are always directed towards a more sustainable model and are increasingly focused on students' needs. In this sense, we must highlight that teachers are changing traditional education in a variety of ways by taking increased advantage of technologies, including a heightened focus on distance education and its multiple possibilities of use in their classrooms, and using them as a way to eliminate inequalities of participation and the digital divide in society [6,37].

It should be noted that the principal tool being used is M-Learning (36.84\%). In recent years, research shows that mobile learning is becoming highly relevant, expanding rapidly throughout the world. This is due to its low cost which allows it to be used by all and its ability to facilitate instant access to information at any time and in any place $[30,31]$. Another of the main strategies being used is E-Learning $(15.79 \%)$, with the creation of interactive and accessible learning environments, which can reach the majority of the population at any time [32]. These two types of learning (M-Learning and E-Learning) seem to predominate in comparison to others, because they can provide a pervasive learning without being restricted by space and time, that is, anywhere and at any time [22,24,26,28]. These facts, along with the rest of emerging technologies, have resulted in the attainment of the objectives established by UNESCO for Sustainable Development $[3,17]$. These practices aim to provide a quality education, facilitating learning, as stated in Objective Four, in addition to reducing inequalities and differences [5,31]. Although there is still much to do, this study shows how transformations in the didactic models in the classroom are increasing, largely because teachers are aware of the tremendous potential of these tools in education for promoting student learning, motivation and participation $[7,19,38]$, as well as learning new skills $[23,27,32]$

Finally, with reference to the last research question (Q6), we can establish that the future lines to be addressed include continued research into the development of good practices with ICT for Sustainable Development in the different stages of education, with the aim of verifying whether these are being developed at all educational levels or to identify the limitations they may encounter. Likewise, research continues to make progress in understanding how good educational practices are related to ICT for Sustainable Development. It is essential to support studies that take advantage of ICT to transform the educational system, since they favor equal opportunities and improve learning that leads to quality education $[4,18,21,39]$.

This aim of this study was to analyze the scientific production in the last decade in the field of ICT in education as a strategy for sustainable development. By means of a review, it has been possible to provide an overview of the general state of scientific production in this area, highlighting that, although in recent years there has been an increase in production, research in this area is still in the initial phase vis-à-vis other themes [33,34]. We can conclude that the integration of ICT can have a positive impact on education from the perspective of sustainability [16,20]. In this sense, ICT teaching practices have been increasing in recent years. This is one of the challenges that teachers must face: to promote the use of sustainable technology to improve the quality of education.

\section{Limitations}

Throughout this study, different limitations have been found due to the scarcity of experiences that relate ICT as a strategy for sustainable development in education. This limitation may be due to the fact that this review has been limited to the search for publications in the two databases with the greatest scientific impact (WoS and Scopus).

Finally, it should be pointed out that research should continue in this field, since some studies reveal that the integration of ICTs in society is essential, pointing out a clear relationship between the 
improvement of quality of life and technologies. People who have access to digital resources in regions that are committed to sustainable development are happier [1].

Author Contributions: Conceptualization, J.J.C.-M. and J.F.-C.; Data curation, J.F.-C.; Formal analysis, A.L.-d.1.R.; Investigation, M.M.-R.; Methodology, J.F.-C. and M.M.-R.; Software, J.F.-C. and M.M.-R.; Supervision, J.J.C.-M. and A.L.-.d.l.R.; Writing—original draft, J.J.C.-M., A.L.-.d.l.R., J.F.-C. and M.M.-R.; Writing-review \& editing, J.J.C.-M., A.L.-d.l.R. and M.M.-R. All authors have read and agreed to the published version of the manuscript.

Funding: The study has been funded by the Spanish Ministry of Economy and Competitiveness, within the framework of the State Plan for the Promotion of Scientific and Technical Research of Excellence 2013-2016 (DIFOTICYD EDU2016 75232-P).

Conflicts of Interest: The authors declare no conflict of interest.

\section{References}

1. Nevado-Peña, D.; López-Ruiz, V.R.; Alfaro-Navarro, J.L. Improving quality of life perception with ICT use and technological capacity in Europe. Technol. Forecast. Soc. Chang. 2019, 148. [CrossRef]

2. Fernández-Portillo, A.; Almodóvar-González, M.; Coca-Pérez, J.L.; Jiménez-Naranjo, H.V. Is sustainable economic development possible thank to the deployment of ICT? Sustainability 2019, 11, 6307. [CrossRef]

3. UNESCO. Education for Sustainable Development Goals: Learning Objectives. 2017. Available online: https://unesdoc.unesco.org/ark:/48223/pf0000247444 (accessed on 3 February 2020).

4. Del Cerro Velázquez, F.; Morales, G. Augmented Reality and Mobile Devices: A Binominal Methodological Resource for Inclusive Education (SDG 4). An Example in Secondary Education. Sustainability 2018, 10, 3446. [CrossRef]

5. Castells, M. Information Technology, Globalization and Social Development; UNRISD: Geneva, Switzerland, 1999.

6. Cabero, J. Las TIC como elementos para la flexibilización de los espacios educativos: Retos y preocupaciones. Comunicación y Pedagogía 2004, 194, 13-19.

7. Colás Bravo, M.P.; de Pablos Pons, J.; Ballesta Pagán, J. The impact of ICT on Teaching in the Spanish Education System: A literature review. RiedRev. De Educ. A Distancia 2018, 56, 1-23.

8. Carranza, M.A. Las TIC, Sustentabilidad y Educación Ambiental. Razón Y Palabra 2007, 58, 1-10.

9. Ibujes Villacis, J.M.; Franco-Crespo, A. Use of ICT and its relationship with the Objectives of Sustainable Development in Ecuador. RetosRev. De Cienc. De La Adm. Y Econ. 2019, 9, 37-53.

10. United Nations Organizations. The 17 Sustainable Development Goals. 2015. Available online: https: //www.un.org/sustainabledevelopment/es/objetivos-de-desarrollo-sostenible/ (accessed on 5 February 2020).

11. Murga Menoyo, M.A. La década de la educación por el Desarrollo sostenible. Antecedentes y significados. BordónRev. De Pedagog. 2009, 6, 19-120.

12. McGarr, O. Education for sustainable development in technology education in Irish schools: A curriculum analysis. Int. J. Technol. Des. Educ. 2009, 20, 317-332. [CrossRef]

13. Vare, P.; Scott, W. Education for Sustainable Development: Two sides and an Edge; DEA: London, UK, 2008.

14. Urrutia, G.; Bonfill, X. Declaración PRISMA: Una propuesta para mejorar la publicación de revisiones sistemáticas y metaanálisis. Med. Clínica 2010, 135, 507-511. [CrossRef]

15. Knoke, D.; Yang, S. Social Network Analysis; Sage Publications: Los Angeles, CA, USA, 2008.

16. Purg, P.; Zakrajšek, S. New technologies for sustainable teaching and learning: A case study from Slovenia on diminishing student workload and increasing motivation through ICT. J. Teach. Educ. Sustain. 2009, 11,31-40. [CrossRef]

17. Grönlund, ̊̊.; Islam, Y.M. A mobile e-learning environment for developing countries: The Bangladesh virtual interactive classroom. Inf. Technol. Dev. 2010, 16, 244-259. [CrossRef]

18. Zhou, C.; Purushothaman, A.; Rongbutsri, N. Facilitating sustainability of education by problem-based learning (PBL) and information and communication technology (ICT). Int. J. Emerg. Technol. Learn. 2013, 8, 50-54. [CrossRef]

19. Kadir, H.; Kadir, M.; Yusuf, T.M.; Rasheed, D. Role of ICTs in Enhancing a Sustainable Educational Development in Selected Secondary Schools in Ilorin Metropolis. J. Econ. Sustain. Dev. 2014, 5, 89-93.

20. Altomonte, S.; Logan, B.; Feisst, M.; Rutherford, P.; Wilson, R. Interactive and situated learning in education for sustainability. Int. J. Sustain. High. Educ. 2016, 17, 417-443. [CrossRef] 
21. Cukurbasi, B.; Isbulan, O.; Chopper, M. Acceptance of Educational Use of Tablet Computers: A Critical View of the FATIH Project. Educ. Sci. 2016, 41, 67-82. [CrossRef]

22. Kalogiannakis, M.; Papadakis, S. Combining mobile technologies in environmental education: A Greek case study. Int. J. Mob. Learn. Organ. 2017, 11, 108-130. [CrossRef]

23. Chou, P.N. Smart Technology for Sustainable Curriculum: Using Drone to Support Young Students' Learning. Sustainability 2019, 10, 3819. [CrossRef]

24. Kim, S. ICT and the UN's Sustainable Development Goal for Education: Using ICT to Boost the Math Performance of Immigrant Youths in the US. Sustainability 2018, 10, 4584. [CrossRef]

25. Plaza-De la Hoz, J. How to improve the use of ICT to promote empowerment in education in sustainable development. Aloma 2018, 36, 43-55.

26. Tu, S.; Yan, X.; Ying, M.; Huang, C. WeChat: An applicable and flexible social app software for mobile teaching. Multimed. Biochem. Mol. Biol. Educ. 2018, 46, 555-560. [CrossRef]

27. Zhalgasbekova, Z.K.; Shakhanova, G.A.; Karymsakova, A.E.; Tutkyshbayeva, S.S.; Kutpanova, Z.A.; Abdualiyeva, R.E.; Shyndaliyev, N. Creating and using mobile physics and mathematics applications in the learning process as one of teaching methods to increase the quality of student's knowledge. Eurasia J. Math. Sci. Technol. Educ. 2018, 14, 1-6. [CrossRef]

28. Bennis, L.; Amali, S. From learning game to adaptive ubiquitous game based learning. Int. J. Emerg. Technol. Learn. 2013, 14, 55-65. [CrossRef]

29. Díaz-Lauzurica, B.; Moreno-Salinas, D. Computational Thinking and Robotics: A Teaching Experience in Compulsory Secondary Education with Students with High Degree of Apathy and Demotivation. Sustainability 2019, 11, 5109. [CrossRef]

30. Hegarty, B.; Thrompson, M. A teacher's influence on student engagement: Using smartphones for creating vocational assessment ePortfolios. J. Inf. Technol. Educ. Res. 2019, 18, 113-159.

31. Lim, K.; Kim, Y.; Kim, M.; Jang, Y.; Joo, M.H. The Digital Divide? Analyzing Regional Differences of Tablet PC Use in Korean Middle Schools for Sustainable Development. Sustainability 2019, 11, 5054. [CrossRef]

32. Verma, P.; Trivedi, A. Online education \& School student: A reality check. Int. J. Recent Technol. Eng. 2019, $8,254-260$.

33. Alonso-García, S.; Aznar-Díaz, I.; Cáceres-Reche, M.P.; Trujillo-Torres, J.M.; Romero-Rodríguez, J.M. Systematic Review of Good Teaching Practices with ICT in Spanish Higher Education. Trends and Challenges for Sustainability. Sustainability 2019, 11, 7150. [CrossRef]

34. Boulahrouz Lahmidi, M.; Medir Huerta, R.M.; Calabuig i Serra, S. Digital technologies and education for sustainable development. An analysis of scientific production. Pixel-Bit Rev. De Medios Y Educ. 2019, 54, 83-105. [CrossRef]

35. Fernández Batanero, J.M.; Cabero J y López, E. Knowledge and Degree of Training of Primary Education Teachers in Relation to ICT Taught to Students with Disabilities. Br. J. Educ. Technol. 2019, 50, 1961-1978. [CrossRef]

36. Maestre Góngora, G.P. Literature review on smart cities: An ICT-centered perspective. Ingeniare 2015, 11, 137-149. [CrossRef]

37. Komba, W. Increasing education access through open and distance learning in Tanzania: A critical review of approaches and practices. Learn. Technol. Libr. 2009, 5, 8-21.

38. Pozo Sánchez, S.; López Belmonte, J.; Moreno Guerrero, A.J.; López Nuñez, J.A. Impact of Educational Stage in the Application of Flipped Learning: A contrasting analysis with traditional teaching. Sustainabily 2019, 11, 5968. [CrossRef]

39. López Belmonte, J.; Fuentes Cabrera, A.; López Núñez, J.A.; Pozo Sánchez, S. Formative Transcendence of Flipped Learning in Mathematics Students of Secondary Education. Mathematics 2019, 7, 1226. [CrossRef]

(C) 2020 by the authors. Licensee MDPI, Basel, Switzerland. This article is an open access article distributed under the terms and conditions of the Creative Commons Attribution (CC BY) license (http://creativecommons.org/licenses/by/4.0/). 